\title{
Thermal stability of lead sulfide and lead oxide nano-crystalline materials
}

\author{
M. Nafees ${ }^{1}$ (D) M. $\operatorname{Ikram}^{2} \cdot$ S. Ali ${ }^{1,2}$
}

Received: 16 June 2017/ Accepted: 21 July 2017/Published online: 2 August 2017

(c) The Author(s) 2017. This article is an open access publication

\begin{abstract}
In this study, nano-crystalline lead sulfide $(\mathrm{PbS})$ and lead oxide $(\mathrm{PbO})$ were synthesized using hassle-free and cost-effective chemical route. Lead oxalate $\left(\mathrm{PbC}_{2} \mathrm{O}_{4}\right)$ precursor was thermally decomposed to obtain the nanocrystalline $\mathrm{PbO}$, while $\mathrm{PbS}$ nanoparticles were synthesized by microwave irradiation on a mixture of $\mathrm{PbC}_{2} \mathrm{O}_{4}$ precursor and sodium thiosulfate. Resulting materials were characterized by X-ray diffraction (XRD), scanning electron microscopy (SEM), Fourier transform infrared spectroscopy, ultraviolet-visible (UV-Vis) spectrophotometry, differential scanning calorimetry (DSC), and thermogravimetric analysis (TGA). XRD confirmed the tetragonal structure for $\mathrm{PbO}$ and face-centered cubic for $\mathrm{PbS}$ with average crystallite sizes varying from 20 to $30 \mathrm{~nm}$ for both materials. From UV-Vis spectra, direct band gap energies were calculated to be 2.51 and $2.23 \mathrm{eV}$ for $\mathrm{PbO}$ and $\mathrm{PbS}$, respectively. Various decomposition stages during heat treatment of $\mathrm{PbO}$ and $\mathrm{PbS}$, as revealed by TGA/DSC, are discussed in detail.
\end{abstract}

Keywords Lead sulfide - Lead oxide - Nanoparticles · Thermal decomposition - Thermogravimetric analysis

M. Nafees

rajvi_gcu@yahoo.com

1 Material and Nano Science Research Lab (MNRL), Department of Physics, Government College University, Lahore, Punjab 54000, Pakistan

2 Solar Applications Research Lab, Department of Physics, Government College University, Lahore, Punjab 54000, Pakistan

\section{Introduction}

In recent times, semiconducting nanomaterials have attracted lot of attention due to their commendable physical and chemical properties which can be tuned by adjusting their shape, size, and surface morphology (Chan 1998; Chang et al. 2004; Milliron et al. 2004; Murray et al. 1993). These properties depend directly on the crystal structure of the material which can be controlled by manipulating thermodynamic and kinetic processes involved in the crystal growth. Therefore, studies relating to the crystal structure and properties are essential to realize potential applications these materials have to offer. Lead-based compounds demonstrate interesting chemical and physical characteristics and are widely used in many applications such as FE transistor, photoresistors, diode, lasers, optical detectors, hybrid organic solar cells, and imaging-labeling applications (Xiao et al. 2013; Patil et al. 2006; Ikram et al. 2014, 2016; So et al. 2017). Lead oxide, which is one of the basic lead compounds, exists in different stoichiometric forms depending on the lead-to-oxygen ratio, e.g., $\mathrm{PbO}$, $\mathrm{PbO}_{2}, \mathrm{~Pb}_{2} \mathrm{O}_{3}, \mathrm{~Pb}_{3} \mathrm{O}_{4}$, and $\mathrm{Pb}_{9} \mathrm{O}_{12}$. Among these, $\mathrm{PbO}, \mathrm{a}$ direct band gap semiconductor having two polymorphs $\alpha$ $\mathrm{PbO}$ and $\beta-\mathrm{PbO}$ with band gap energies of 2.2 and $2.5 \mathrm{eV}$, respectively, has attracted a greater focus due its exceptional mechanical, electronic, and optical properties (Karami and Alipour 2009; Lafront et al. 2010; Martos et al. 2001; Xi et al. 2004). Another important lead compound is $\mathrm{PbS}$. It is a subject of growing attention due to its exclusive properties associated with size quantization. Bulk $\mathrm{PbS}$ has cubic crystal structure and a small direct band gap of $0.41 \mathrm{eV}$ at $300 \mathrm{~K}$ and a large Bohr radius (around $18 \mathrm{~nm}$ ). A blend of these extraordinary properties makes $\mathrm{PbS}$ a very promising candidate for electroluminescent devices (Wang et al. 1987). Recent approaches for the synthesis of $\mathrm{PbO}$ 
and $\mathrm{PbS}$ nanostructures include sonochemical methods, thermal decomposition, self-organization (Leontidis 2003), hydrothermal synthesis ( $\mathrm{Li}$ et al. 2009), homogeneous hydrolysis ( $\mathrm{Li}$ et al. 2007), electro deposition (Sharon et al. 1997), and microwave heating (Ding et al. 2003; Sun et al. 2009). Utilization of $\mathrm{PbO}$ and $\mathrm{PbS}$ nanostructures for potential applications is strongly subjected to their thermal stability in air and inert atmosphere. Structural phase transitions, oxidation, and recrystallization occur rapidly in metal sulfides upon small increments of temperature (Nafees et al. 2011, 2012, 2015; Qadri et al. 2003; Sadovnikov et al. 2009, 2011; Sadovnikov and Rempel 2009). Therefore, a better understanding of oxidation temperature/resistance and thermal stability of $\mathrm{PbO}$ and $\mathrm{PbS}$ is crucial for realizing potential applications these materials promise. Still, sufficient literature on these issues is not available.

In this work, we report the simple and cost-effective aqueous medium-based chemical method to synthesize $\mathrm{PbO}$ and $\mathrm{PbS}$ using a single precursor. Thermal stability and various transitions/reactions occurring in nanostructured $\mathrm{PbO}$ and $\mathrm{PbS}$ during heat treatment in air and inert atmosphere are also discussed in detail.

\section{Experimental work}

\section{Materials}

Analytical grade pure lead (II) chloride $\left(\mathrm{PbCl}_{2}\right)$, sodium thiosulfate $\mathrm{Na}_{2} \mathrm{~S}_{2} \mathrm{O}_{3}$, and oxalic acid $\left(\mathrm{H}_{2} \mathrm{C}_{2} \mathrm{O}_{4}\right)$ were purchased from Unichem Laboratories Ltd. Absolute ethanol and distilled water were used to wash the products. All chemicals were used without any further purification.

\section{Preparation of lead oxalate precursor}

Separate solutions of desired molarity were prepared by dissolving $\mathrm{PbCl}_{2}$ and $\mathrm{H}_{2} \mathrm{C}_{2} \mathrm{O}_{4}$ in distilled water under vigorous stirring at room temperature then these solutions were mixed dropwise under the same condition. White precipitate of lead oxalate $\left(\mathrm{PbC}_{2} \mathrm{O}_{4}\right)$ was produced which was collected and washed with absolute ethanol and distilled water several times to remove the traces of impurities. As prepared $\mathrm{PbC}_{2} \mathrm{O}_{4}$ was dried by aging for $7 \mathrm{~h}$ at $60{ }^{\circ} \mathrm{C}$.

\section{Preparation of lead oxide}

Dry $\mathrm{PbC}_{2} \mathrm{O}_{4}$ was heated for $3 \mathrm{~h}$ at $425^{\circ} \mathrm{C}$ in a muffle furnace with the ramp rate of $20{ }^{\circ} \mathrm{C} \mathrm{min}{ }^{-1}$. After cooling naturally to room temperature (RT), red-colored $\mathrm{PbO}$ was formed and collected for characterization.
Chemical reactions involved in the synthesis are:

$$
\begin{aligned}
& \mathrm{H}_{2} \mathrm{C}_{2} \mathrm{O}_{4}+\mathrm{PbCl}_{2} \rightarrow \mathrm{PbC}_{2} \mathrm{O}_{4}+2 \mathrm{HCl} \\
& \mathrm{PbC}_{2} \mathrm{O}_{4} \rightarrow \mathrm{PbO}+\mathrm{CO}_{2}+\mathrm{CO}
\end{aligned}
$$

Preparation of lead sulfide

For the synthesis of $\mathrm{PbS}$ nano-crystalline material, solution of required molarity was prepared by dissolving $\mathrm{Na}_{2} \mathrm{~S}_{2} \mathrm{O}_{3}$ in distilled water before the addition of as prepared $\mathrm{PbC}_{2} \mathrm{O}_{4}$ precursor under stirring.

After $2 \mathrm{~h}$ of stirring, resulting solution was heated/irradiated in microwave oven $(2.45 \mathrm{GHz}, 1000 \mathrm{~W})$ for $40 \mathrm{~min}$ with $20 \%$ power. Upon heating, the black precipitate was formed then filtered and washed with distilled water and absolute ethanol before being dried at room temperature.

The reaction between $\mathrm{PbC}_{2} \mathrm{O}_{4}$ and $\mathrm{Na}_{2} \mathrm{~S}_{2} \mathrm{O}_{3}$ involves multiple steps similar to those reported for $\mathrm{CuS}$ synthesis (Nafees et al. 2012, 2015). At first, $\mathrm{S}_{2} \mathrm{O}_{3}{ }^{2-}$ ions from $\mathrm{Na}_{2} \mathrm{~S}_{2} \mathrm{O}_{3}$ react with water molecules to form $\mathrm{H}_{2} \mathrm{~S}$ gas which, upon reacting with $\mathrm{Pb}^{2+}$ ions from $\mathrm{PbC}_{2} \mathrm{O}_{4}$, results in the formation of $\mathrm{PbS}$ nanoparticles, further aggregated to the nano-crystalline material. A simplified reaction scheme is presented in Fig. 1.

\section{Characterization}

Structural and phase information on $\mathrm{PbO}$ and $\mathrm{PbS}$ nanoparticles were obtained using PANalytical X'Pert PRO X-ray diffractometer with $\mathrm{Cu} \mathrm{K} \alpha$ radiation $(\lambda=0.15418 \mathrm{~nm})$. X-ray diffraction (XRD) patterns were recorded in the $2 \theta$ range of $20-75$ using a step size of $0.05^{\circ} \mathrm{s}^{-1}$. Morphology and microstructure of the synthesized materials were probed using field emission scanning electron microscope (SEM, JOEL JSM-6480). Differential scanning calorimeter (DSC) and thermogravimetric analysis (TGA) were performed by TGA, SDT Q600 (TA Instrument) in controlled environment to observe the mass loss/increment, thermal phase transitions, and thermal

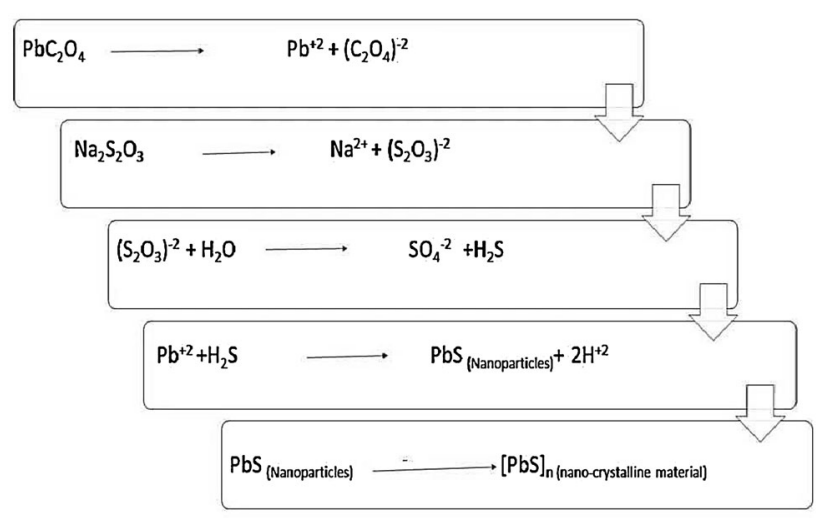

Fig. 1 Reaction scheme for synthesis of lead sulfide $\mathrm{PbS}$ 


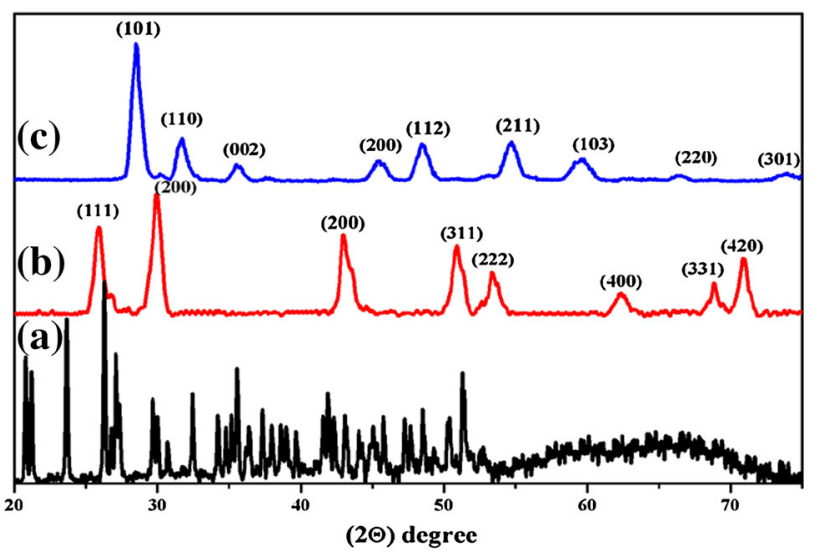

Fig. 2 XRD pattern of $\mathbf{a ~}_{2} \mathrm{PbO}_{4}, \mathbf{b} \mathrm{PbS}$, and $\mathbf{c} \mathrm{PbO}$

decomposition/oxidation in $\mathrm{PbS}$ nanomaterial. Thermal analysis was carried out using TA Universal Analysis 2000. Fourier transform infrared (FTIR) spectra were recorded from 4000 to $400 \mathrm{~cm}^{-1}$ using a PerkinElmer spectrum two universal attenuated total reflectance Fourier transform infrared (UATR-FTIR) spectrometer. Ultraviolet-visible (UV-Vis) spectra were recorded using Genesys $10 \mathrm{~s}$ UV-Vis spectrophotometer.

\section{Results and discussion}

XRD patterns of nano-crystalline $\mathrm{PbO}, \mathrm{PbS}$, and $\mathrm{PbC}_{2} \mathrm{O}_{4}$ are represented in Fig. 2. It can be observed that all synthesized products demonstrate high crystallinity and match well with reported patterns as mentioned in JCPDS card numbers $\left(\mathrm{PbC}_{2} \mathrm{O}_{4}, 00-014-0803\right.$; $\mathrm{PbO}, 01-085-1414 ; \mathrm{PbS}$, 03-065-2935). XRD pattern of $\mathrm{PbO}$ (Fig. 2c) is indexed as tetragonal, a very small peak present at $30.25(2 \theta)$ shows the presence of orthorhombic phase. Long heating time required to decompose $\mathrm{PbC}_{2} \mathrm{O}_{4}$ precursor results in the phase change and a corresponding appearance of the additional peak. $\mathrm{PbS}$ crystallizes in face-centered cubic crystal system with the presence of no other phases. Average crystallite size for $\mathrm{PbO}$ and $\mathrm{PbS}$ was found to be around $20-30 \mathrm{~nm}$ as calculated by Scherer's formula. Optical absorbance and band gap energies for $\mathrm{PbO}$ and $\mathrm{PbS}$ are shown in Fig. 3. Both the $\mathrm{PbO}$ and $\mathrm{PbS}$ absorb in ultraviolet and visible regions with respective band gap energies of 2.51 and 2.23 .

The optical absorption with band gap energies of $\mathrm{PbO}$ and $\mathrm{PbS}$ are shown in Fig. 3a, b, respectively. The $\mathrm{PbO}$ absorption was in UV as well as in visible region while $\mathrm{PbS}$ absorption was maximum around $375 \mathrm{~nm}$ (Fig. 3a) and their corresponding band gap energies were calculated using a Tauc plot, shows $(\alpha h v)^{2}$ vs $h v$ for the nanoparticles. The intersection of the straight line with $x$-axis indicates that the calculated band gap energy $\left(E_{\mathrm{g}}\right)$ for $\mathrm{PbO}$ and $\mathrm{PbS}$ was 2.95 and $2.15 \mathrm{eV}$, respectively.

Figure 4 shows the energy dispersive $\mathrm{X}$-ray spectroscopy (EDX) results of as prepared $\mathrm{PbS}$ and $\mathrm{PbO}$. Figure 4a indicates that $\mathrm{PbS}$ sample contains $\mathrm{Pb}, \mathrm{S}, \mathrm{Na}$, and $\mathrm{O}$; the presence of $\mathrm{Na}$ and $\mathrm{O}$ corresponds to $\mathrm{Na}_{2} \mathrm{~S}_{2} \mathrm{O}_{3}$ which remained unreactive during synthesis. EDX spectrum of $\mathrm{PbO}$ consists of peaks corresponding to $\mathrm{Pb}$ and $\mathrm{O}$. Absence of additional peaks confirms the high purity of the sample.

Surface morphology and microstructure of $\mathrm{PbS}$ and $\mathrm{PbO}$ were probed by field emission scanning electron microscopy (FESEM) images of $\mathrm{PbO}$ and $\mathrm{PbS}$ as shown in Fig. 5. It is clear that $\mathrm{PbS}$ nanoparticles exist in cubic geometry with significant agglomeration as shown in Fig. 5a, b. The increase in particle size occurs mainly due to aggregation of nanoparticles depending on reaction parameters like reaction time, microwave power, and (a)

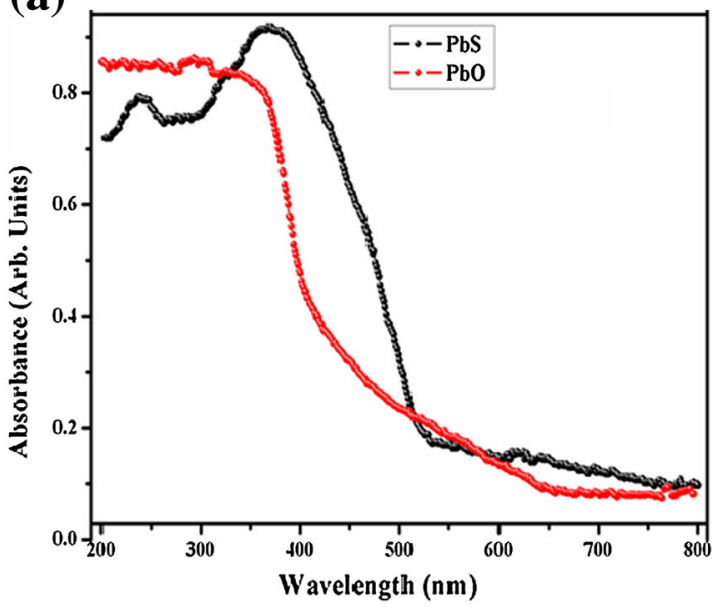

(b)

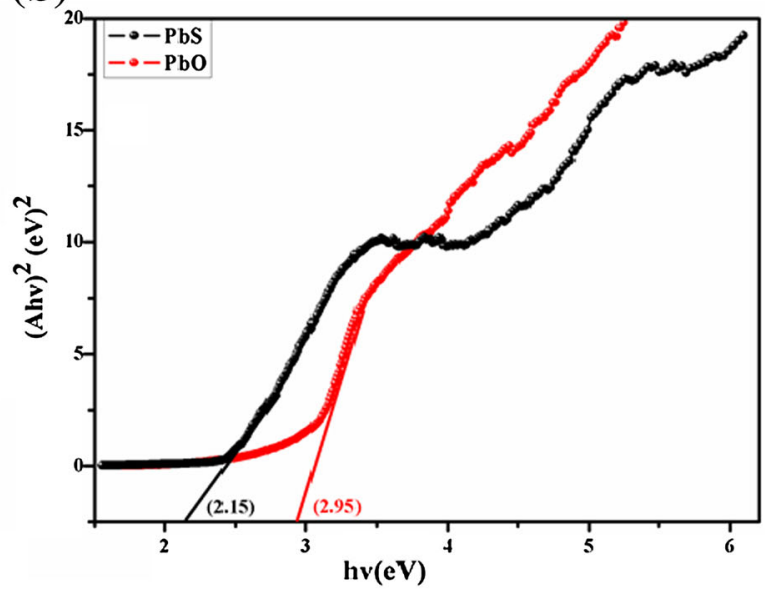

Fig. 3 Optical absorption of metal oxide and sulfide (a) and calculation of band gap energies (b) 

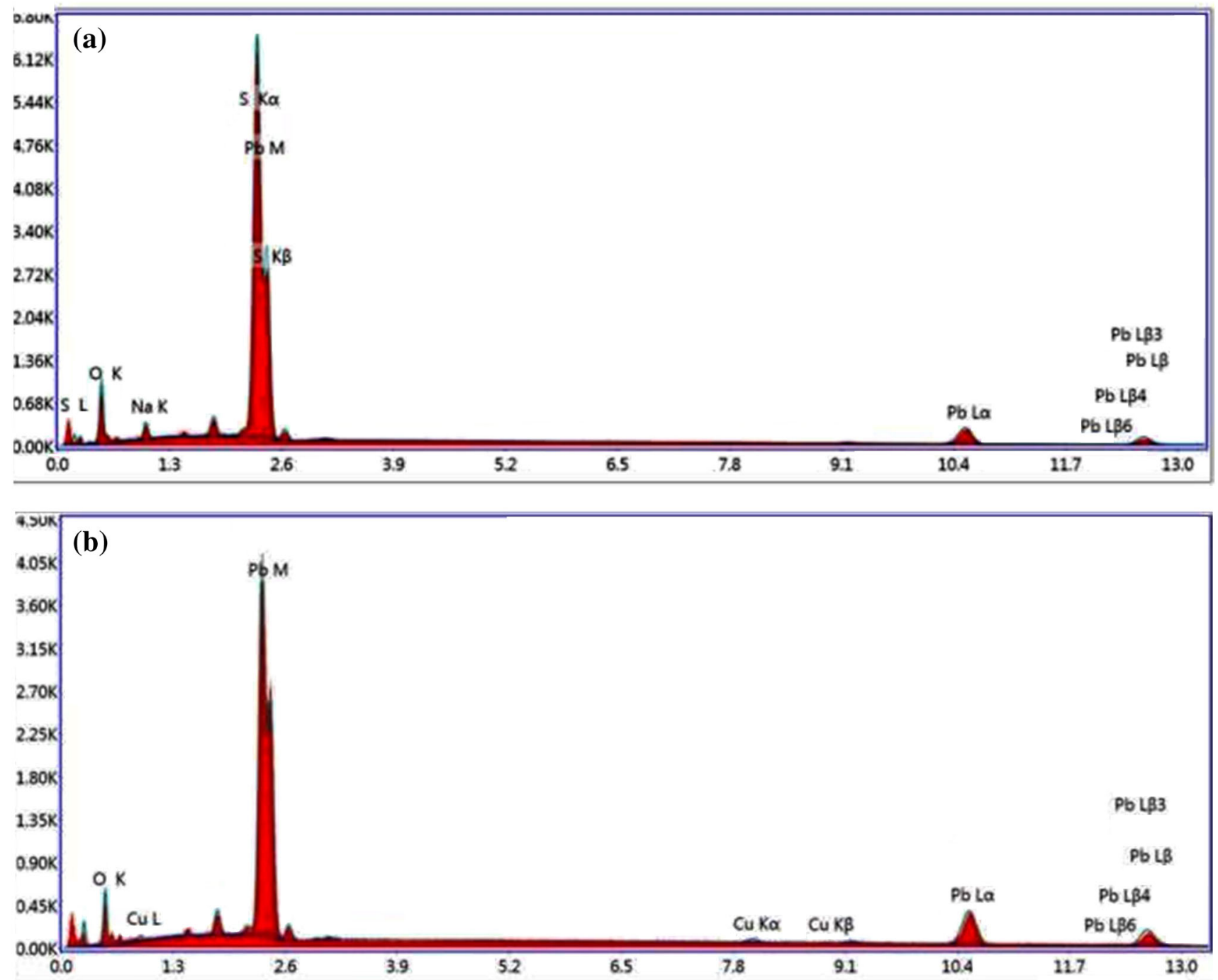

Fig. 4 EDX of a $\mathrm{PbS}$ nanoparticles and $\mathbf{b} \mathrm{PbO}$

Fig. 5 FESEM images of a, b $\mathrm{PbS}$ and $\mathbf{c}, \mathbf{d} \mathrm{PbO}$
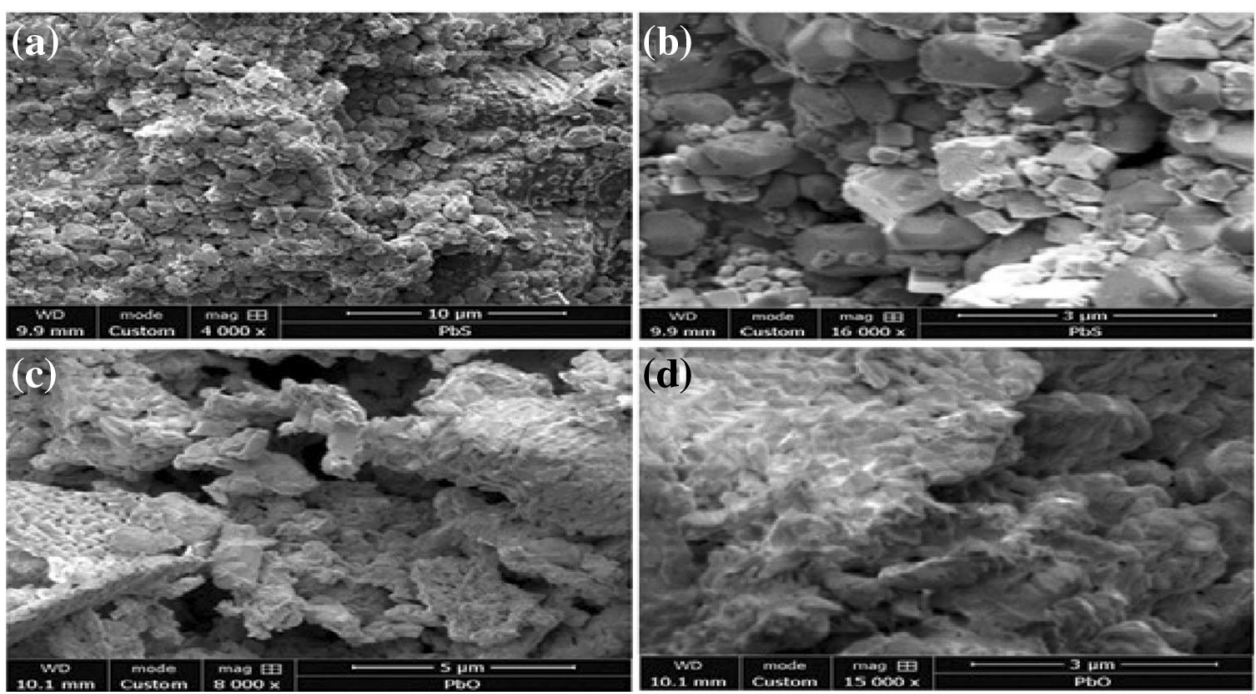


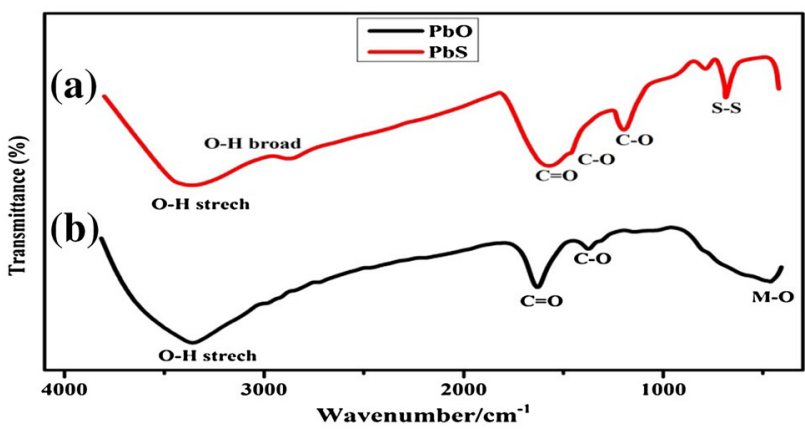

Fig. 6 FTIR spectra of a $\mathrm{PbO}$ and $\mathbf{b} \mathrm{PbS}$ nanoparticles

concentration of precursors. Particle size and shape can be controlled by tuning these parameters.

Figure $5 \mathrm{c}, \mathrm{d}$ reveals the presence of very fine $\mathrm{PbO}$ nanoparticles. Amalgamation of these nanoparticles leads to the formation of porous structures with very narrow pore size in the $40-100 \mathrm{~nm}$ range.

Fourier transform infrared (FTIR) spectra of $\mathrm{PbO}$ and $\mathrm{PbS}$ nanoparticles are shown in Fig. 6. The board peak around $3400 \mathrm{~cm}^{-1}$ corresponds to $(\mathrm{O}-\mathrm{H})$ stretching vibrations originating due to small amount of ethanol used in washing the samples. A sharp peak at $1705 \mathrm{~cm}^{-1}$, in both graphs is assigned to vibrations of the carbonyl group $(\mathrm{C}=\mathrm{O})$, while another peak at $1395 \mathrm{~cm}^{-1}$ is recognized as stretching vibration of carboxyl group $(\mathrm{C}-\mathrm{O})$. Peaks lying in the $300-900 \mathrm{~cm}^{-1}$ are identified as metal-oxygen (MO) stretching vibrations. Although the FTIR spectra of $\mathrm{PbO}$ and $\mathrm{PbS}$ are identical, a well-defined peak around $600 \mathrm{~cm}^{-1}$ in $\mathrm{PbS}$ spectra is assigned to (S-S) stretching vibrations (Bakshi et al. 2007; Senvaitiene et al. 2007; Timar and Lucăcel-Ciceo 2008).

Differential scanning calorimetry and thermogravimetric analysis (DSC/TGA) curves of $\mathrm{PbC}_{2} \mathrm{O}_{4}$ precursor recorded in air are shown in Fig. 7. Sample was heated from room temperature to $500{ }^{\circ} \mathrm{C}$ with the ramp rate of $10{ }^{\circ} \mathrm{C} \mathrm{min}^{-1}$. No significant mass loss was observed up to $325^{\circ} \mathrm{C}$ indicating that sample was free from moisture and solvent molecules. A notable mass loss $(26 \%)$ occurs between 350 and $400{ }^{\circ} \mathrm{C}$ due to decomposition of $\mathrm{Pb}_{2} \mathrm{C}_{2} \mathrm{O}_{4}$ to $\mathrm{PbO}$ with a corresponding endothermic peak appearing at $390{ }^{\circ} \mathrm{C}$.

For $\mathrm{PbO}, \mathrm{DSC} / \mathrm{TGA}$ curves were recorded from room temperature (RT) to $1175{ }^{\circ} \mathrm{C}$ in air with the ramp rate of $10{ }^{\circ} \mathrm{C} \mathrm{min}{ }^{-1}$. A mass loss of almost $2 \%$ occurs up to $500{ }^{\circ} \mathrm{C}$ as shown in Fig. 7. This initial mass loss involves multiple transitions occurring during the heating process (Nafees et al. 2011, 2012). As observed from differential thermogravimetric (DTGA) curve, dehydration takes place first resulting in the removal of water of crystallization around $100{ }^{\circ} \mathrm{C}$ while a hump between 200 and $250{ }^{\circ} \mathrm{C}$ corresponds to
Fig. 7 DSC/TGA curves of as prepared precursor $\mathrm{Pb}_{2} \mathrm{C}_{2} \mathrm{O}_{4}$ (above) and $\mathrm{PbO}$ (below) recorded in the air
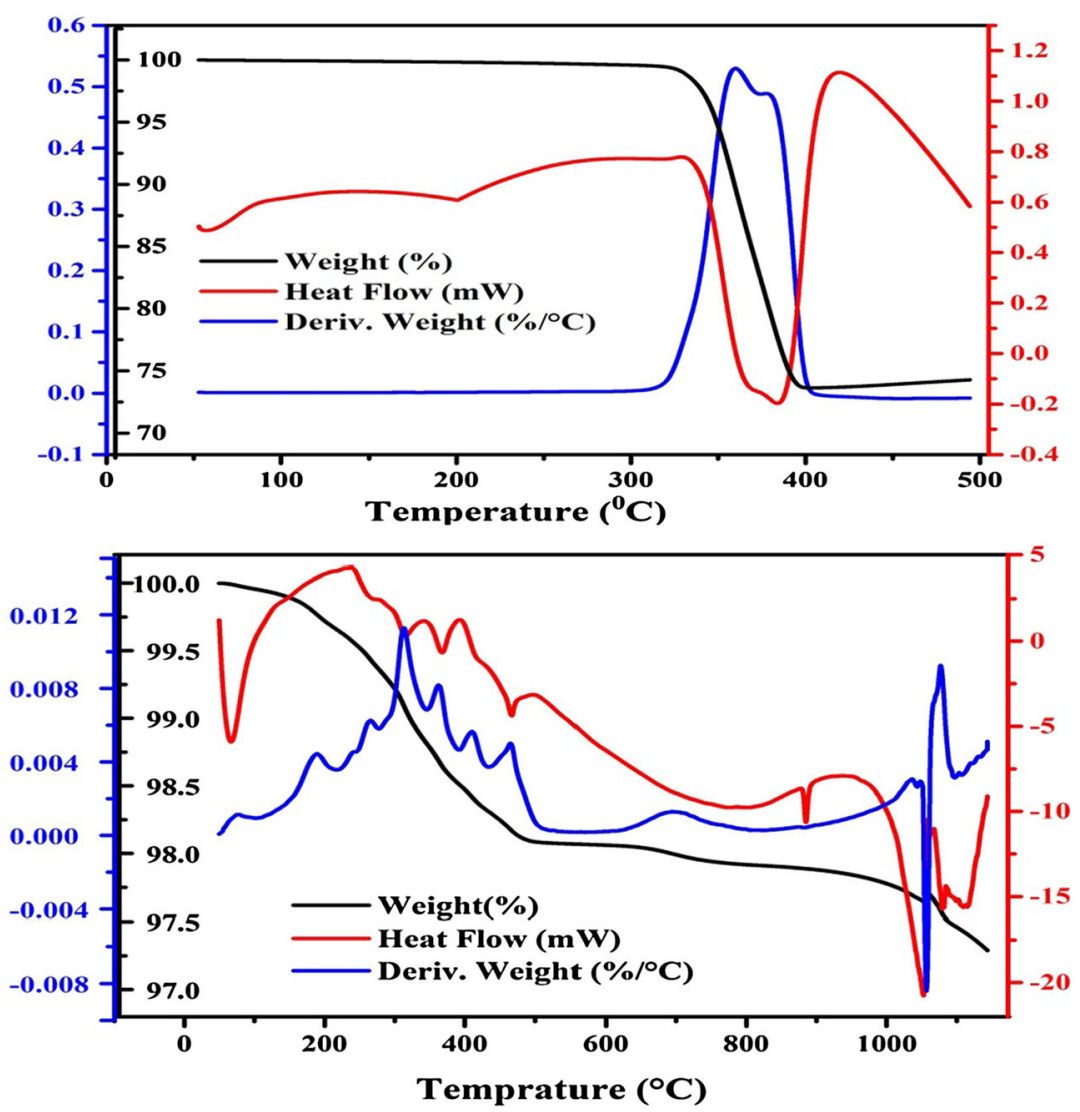

Temprature $\left({ }^{\circ} \mathrm{C}\right)$ 
Fig. $8 \mathrm{DSC} / \mathrm{TGA}$ of $\mathrm{PbS}$ in air (above) and in argon (below)
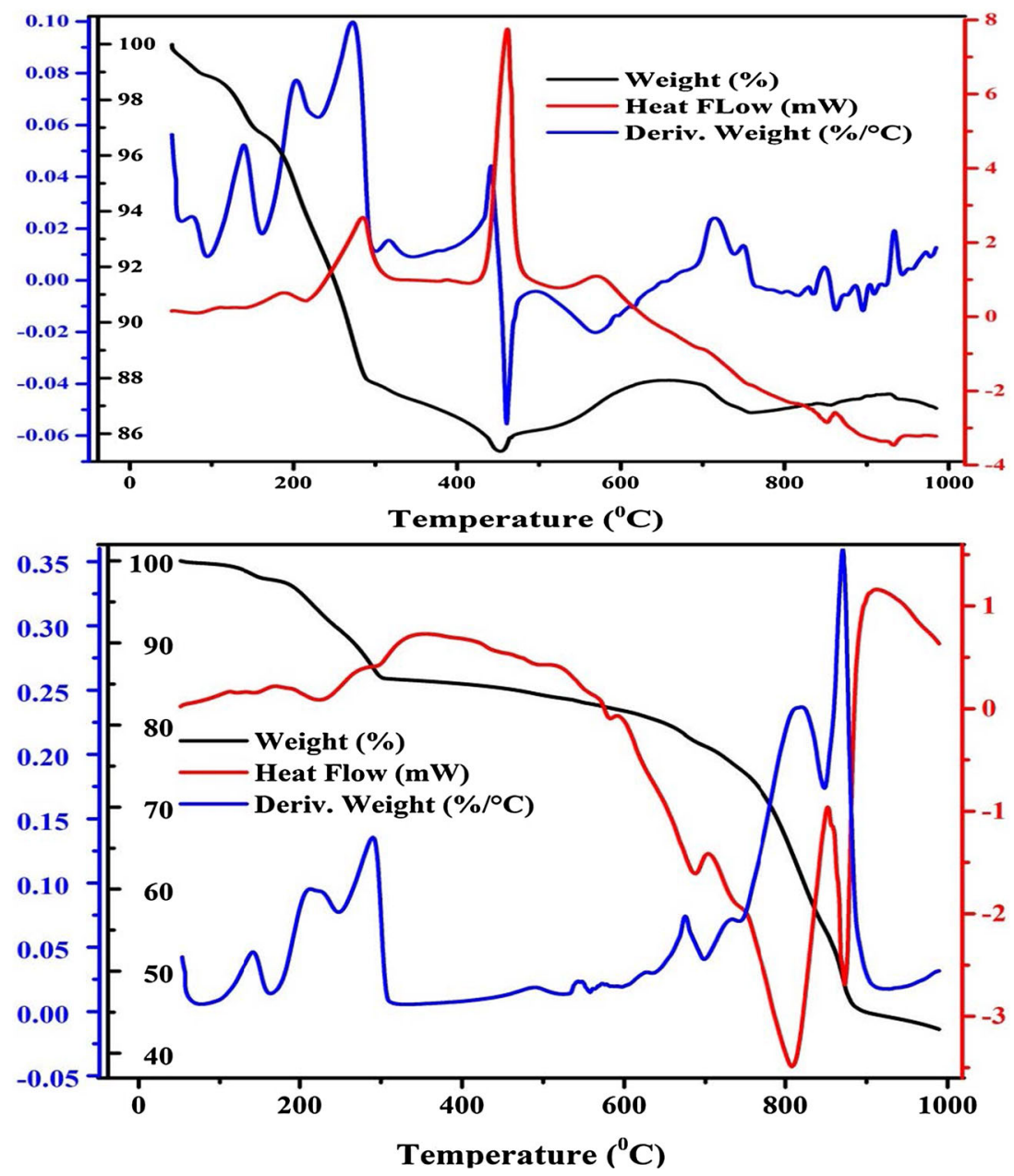

endothermic nature of transition confirmed by DSC curve. The inorganic compound $\mathrm{PbO}$ contains minute quantities of $\mathrm{PbO}_{2}$; thermal decomposition from $\mathrm{PbO}_{2}$ to $\mathrm{PbO}$ occurs in many steps from 290 to $650{ }^{\circ} \mathrm{C}$ accompanied by endothermic mass losses in designated temperatures. Decomposition of $\mathrm{PbO}_{2}$ to $\mathrm{PbO}$ proceeds as follows (Greenwood and Earnshaw 1997; White and Roy 1964):

$$
\begin{aligned}
& 12 \mathrm{PbO}_{2} \stackrel{\text { Above } 293{ }^{\circ} \mathrm{C}}{\longrightarrow} \mathrm{Pb}_{12} \mathrm{O}_{19}+2.5 \mathrm{O}_{2} \\
& \mathrm{~Pb}_{12} \mathrm{O}_{19} \stackrel{\text { Above } 350{ }^{\circ} \mathrm{C}}{\longrightarrow} \mathrm{Pb}_{12} \mathrm{O}_{17}+\mathrm{O}_{2} \\
& \mathrm{~Pb}_{12} \mathrm{O}_{17} \stackrel{\text { Above } 375^{\circ} \mathrm{C}}{\longrightarrow} 4 \mathrm{~Pb}_{3} \mathrm{O}_{4}+0.5 \mathrm{O}_{2} \\
& \mathrm{~Pb}_{3} \mathrm{O}_{4} \stackrel{\text { Above } 605^{\circ} \mathrm{C}}{\longrightarrow} 3 \mathrm{PbO}+0.5 \mathrm{O}_{2}
\end{aligned}
$$

A sharp endothermic peak observed in DSC curve at $880{ }^{\circ} \mathrm{C}$ indicates melting of $\mathrm{PbO}$ without the involvement of any mass loss as supported by TGA and DTGA curves. Around $1100{ }^{\circ} \mathrm{C}$, another endothermic mass loss was observed most probably due to partial evaporation of very small $\mathrm{PbO}$ nanoparticles. A small percentage of mass loss $(2.7 \%)$ from $\mathrm{RT}$ to $1175^{\circ} \mathrm{C}$ indicates excellent thermal stability of $\mathrm{PbO}$ nanoparticles.

Figure 8 shows the DSC/TGA analysis of $\mathrm{PbS}$ at temperature range $25-1000{ }^{\circ} \mathrm{C}$ with the ramp rate of $10{ }^{\circ} \mathrm{C}$ $\min ^{-1}$ in $\operatorname{argon}$ and air atmosphere. TGA curve indicates an initial mass loss of about $20 \%$ from 50 to $300{ }^{\circ} \mathrm{C}$. This is confirmed by DTGA curve which reveals three peaks corresponding to vaporization of water and ethanol contents, removal of water of crystallization and liberation of sulfur at 140,215 , and $290{ }^{\circ} \mathrm{C}$, respectively. The second mass loss from 600 to $900{ }^{\circ} \mathrm{C}$ is attributed to evaporation of sulfur and production of metallic lead $\mathrm{Pb}$ with associated endothermic and DTGA peaks appearing at 810 and $880{ }^{\circ} \mathrm{C}$.

Almost identical behavior was observed in air atmosphere from 25 to $280{ }^{\circ} \mathrm{C}$. In DSC curve, a peak around $290{ }^{\circ} \mathrm{C}$ corresponds to the exothermic reaction of $\mathrm{PbS}$ with oxygen yielding $\mathrm{SO}_{2}$ and $\mathrm{PbO}$ as confirmed by small peak at $310^{\circ} \mathrm{C}$ in DTGA curve. TGA graph shows mass gain from 450 to $700{ }^{\circ} \mathrm{C}$ which is attributed to exothermic reaction at $460{ }^{\circ} \mathrm{C}$ producing $\mathrm{PbSO}_{4}$ and $\mathrm{PbO}$. This is also confirmed by DSC and TGA curves. Furthermore, $\mathrm{PbSO}_{4}$ 
decomposes from 750 to $1000{ }^{\circ} \mathrm{C}$ to $\mathrm{Pb}$. This can be represented in terms of chemical reactions as follows:

$$
\begin{aligned}
& \mathrm{PbS} \cdot \mathrm{H}_{2} \mathrm{O} \rightarrow \mathrm{PbS}+\mathrm{H}_{2} \mathrm{O} \\
& 2 \mathrm{PbS}+3 \mathrm{O}_{2} \rightarrow 2 \mathrm{PbO}+2 \mathrm{SO}_{2} \\
& 2 \mathrm{PbO}+\mathrm{PbS} \rightarrow 3 \mathrm{~Pb}+\mathrm{SO}_{2} \\
& \mathrm{PbS}+2 \mathrm{O}_{2} \rightarrow \mathrm{PbSO}_{4} \\
& \mathrm{PbSO}_{4} \rightarrow \mathrm{Pb}+\mathrm{SO}_{4} \\
& \mathrm{PbS}+\mathrm{PbSO}_{4} \rightarrow 2 \mathrm{~Pb}+2 \mathrm{SO}_{2} .
\end{aligned}
$$

\section{Conclusions}

In this study, cost-effective and low-temperature synthesis of single $\mathrm{Pb}_{2} \mathrm{C}_{2} \mathrm{O}_{4}$ precursor was reported, which is used to synthesize $\mathrm{PbO}$ nano-crystalline material by heating $\mathrm{PbC}_{2} \mathrm{O}_{4}$ at $425{ }^{\circ} \mathrm{C}$ and $\mathrm{PbS}$ nanostructured material was produced by microwave irradiation $(2.45 \mathrm{GHz}, 1000 \mathrm{~W}$, 40 min) on aqueous solution prepared with $\mathrm{Na}_{2} \mathrm{~S}_{2} \mathrm{O}_{3}$ and $\mathrm{PbC}_{2} \mathrm{O}_{4}$ precursor. This synthesis process demands effective and proper washing to remove byproducts.

The formation of $\mathrm{PbO}$ and $\mathrm{PbS}$ was confirmed by XRD, which reveals high crystalline nature of both materials with a crystallite size of 20-30 nm. Optical band gap was found to be 2.15 and $2.95 \mathrm{eV}$ for $\mathrm{PbS}$ and $\mathrm{PbO}$, respectively, using UV-Vis measurements. EDX data vet the presence of $\mathrm{Pb}, \mathrm{S}$, and $\mathrm{O}$ in the synthesized samples. Surface morphology of $\mathrm{PbS}$ nanoparticles was found to be cubic with many particles of sizes less than $100 \mathrm{~nm}$, while $\mathrm{PbO}$ features highly porous surface with very small pore sizes varying from 40 to $100 \mathrm{~nm}$. PbS demonstrates excellent thermal behavior with complete decomposition involving many steps; by heating $\mathrm{PbS}$ in air, system absorbs heat thereby releasing $\mathrm{SO}_{2}$ with the production of $\mathrm{PbO}$ followed by exothermic conversion to $\mathrm{PbSO}_{4}$ and metallic $\mathrm{Pb}$ at higher temperatures from 700 to $1000{ }^{\circ} \mathrm{C}$, simultaneously endothermic decomposition of lead sulfate takes place. No mass increment was detected in argon atmosphere due to the absence of $\mathrm{O}_{2}$. It was noted that small $\mathrm{PbS}$ particles react at low temperature compared with the large size. The proposed research can be used for the cost-effective synthesis of $\mathrm{PbS}, \mathrm{PbO}$, and related materials.

Acknowledgements The authors acknowledge Higher Education Commission, Pakistan, for financial support through "Indigenous Ph.D. Fellowship Program (5000 Fellowships)".

Open Access This article is distributed under the terms of the Creative Commons Attribution 4.0 International License (http:// creativecommons.org/licenses/by/4.0/), which permits unrestricted use, distribution, and reproduction in any medium, provided you give appropriate credit to the original author(s) and the source, provide a link to the Creative Commons license, and indicate if changes were made.

\section{References}

Bakshi MS, Thakur P, Sachar S, Kaur G, Banipal TS, Possmayer F, Petersen NO (2007) Aqueous phase surfactant selective shape controlled synthesis of lead sulfide nanocrystals. J Phys Chem C 111:18087-18098

Chan WC (1998) Quantum dot bioconjugates for ultrasensitive nonisotopic detection. Science 281:2016-2018

Chang T-WF, Musikhin S, Bakueva L, Levina L, Hines MA, Cyr PW, Sargent EH (2004) Efficient excitation transfer from polymer to nanocrystals. Appl Phys Lett 84:4295

Ding T, Zhang J-R, Long S, Zhu J-J (2003) Synthesis of HgS and PbS nanocrystals in a polyol solvent by microwave heating. Microelectron Eng 66:46-52

Greenwood NN, Earnshaw A (1997) Chemistry of the elements, 2nd edn. Reed Educational and Professional, Oxford

Ikram M, Murray R, Hussain A, Ali S, Shah SI (2014) Hybrid organic solar cells using both $\mathrm{ZnO}$ and PCBM as electron acceptor materials. Mater Sci Eng B 189:64-69

Ikram M, Murray R, Imran M, Ali S, Shah SI (2016) Enhanced performance of $\mathrm{P} 3 \mathrm{HT} /\left(\mathrm{PCBM}: \mathrm{ZnO}: \mathrm{TiO}_{2}\right)$ blend based hybrid organic solar cells. Mater Res Bull 75:35-40

Karami H, Alipour M (2009) Investigation of organic expanders effects on the electrochemical behaviors of new synthesized nanostructured lead dioxide and commercial positive plates of lead-acid batteries. J Power Sourc 191:653-661

Lafront A-M, Zhang W, Ghali E, Houlachi G (2010) Electrochemical noise studies of the corrosion behaviour of lead anodes during zinc electrowinning maintenance. Electrochim Acta 55:6665-6675

Leontidis E (2003) Composite nanotubes formed by self-assembly of $\mathrm{PbS}$ nanoparticles. Nano Lett 3:569-572

Li C, Shi G, Xu H, Guang S, Yin R, Song Y (2007) Nonlinear optical properties of the $\mathrm{PbS}$ nanorods synthesized via surfactantassisted hydrolysis. Mater Lett 61:1809-1811

Li F, Huang X, Kong T, Liu X, Qin Q, Li Z (2009) Synthesis and characterization of $\mathrm{PbS}$ crystals via a solvothermal route. J Alloys Compd 485:554-560

Martos M, Morales J, Sánchez L, Ayouchi R, Leinen D, Martin F, Barrado JRR (2001) Electrochemical properties of lead oxide films obtained by spray pyrolysis as negative electrodes for lithium secondary batteries. Electrochim Acta 46:2939-2948

Milliron DJ, Hughes SM, Cui Y, Manna L, Li J, Wang L-W, Alivisatos AP (2004) Colloidal nanocrystal heterostructures with linear and branched topology. Nature 430:190-195

Murray CB, Norris DJ, Bawendi MG (1993) Synthesis and characterization of nearly monodisperse $\mathrm{CdE}(\mathrm{E}=$ sulfur, selenium, tellurium) semiconductor nanocrystallites. J Am Chem Soc 115:8706-8715

Nafees M, Ali S, Rasheed K, Idrees S (2011) The novel and economical way to synthesize $\mathrm{CuS}$ nanomaterial of different morphologies by aqueous medium employing microwaves irradiation. Appl Nanosci 2:157-162

Nafees M, Ali S, Idrees S, Rashid K, Shafique MA (2012) A simple microwave assists aqueous route to synthesis $\mathrm{CuS}$ nanoparticles and further aggregation to spherical shape. Appl Nanosci 3:119-124

Nafees M, Ikram M, Ali S (2015) Thermal behavior and decomposition of copper sulfide nanomaterial synthesized by aqueous sol method. Dig J Nanomater Biostruct 10:635-641

Patil RS, Pathan HM, Gujar TP, Lokhande CD (2006) Characterization of chemically deposited nanocrystalline $\mathrm{PbS}$ thin films. J Mater Sci 41:5723-5725

Qadri SB, Singh A, Yousuf M (2003) Structural stability of PbS films as a function of temperature. Thin Solid Films 431-432:506-510

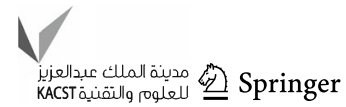


Sadovnikov SI, Rempel AA (2009) Nonstoichiometric distribution of sulfur atoms in lead sulfide structure. Dokl Phys Chem 428:167-171

Sadovnikov SI, Gusev AI, Rempel AA (2009) New crystalline phase in thin lead sulfide films. JETP Lett 89:238-243

Sadovnikov SI, Kozhevnikova NS, Rempel AA (2011) Oxidation of nanocrystalline lead sulfide in air. Russ J Inorg Chem 56:1864-1869

Senvaitiene A, Smirnova J, Beganskiene J, Kareiva A (2007) XRD and FTIR characterisation of lead oxide-based pigments and glazes. Acta Chim Slov 54:185

Sharon M, Ramaiah KS, Kumar M, Neumann-Spallart M, LevyClement C (1997) Electrodeposition of lead sulphide in acidic medium. J Electroanal Chem 436:49-52

So B, Heo J, Liu C, Ju S, Han W-T (2017) Formation of channels containing lead sulfide quantum dots using continuous-wave laser for active planar waveguides in glasses. Opt Mater Express $7: 281-285$
Sun J-Q, Shen X-P, Guo L-J, Chen K-M, Liu Q (2009) Microwaveassisted synthesis of flower-like PbS crystals. Phys E Low Dimens Syst Nanostruct 41:1527-1532

Timar V, Lucăcel-Ciceo R (2008) Structural studies of iron doped $3 \mathrm{~B}_{2} \mathrm{O}_{3} \cdot 0.7 \mathrm{PbO} \cdot 0.3 \mathrm{Ag}_{2} \mathrm{O}$ glasses by FT-IR and Raman spectroscopies. Semicond Phys Quantum Electron Optoelectron 11:221-225

Wang Y, Suna A, Mahler W, Kasowski R (1987) PbS in polymers. From molecules to bulk solids. J Chem Phys 87:7315

White WB, Roy R (1964) Phase relations in the system lead-oxygen. J Am Ceram Soc 47:242-249

Xi G, Peng Y, Xu L, Zhang M, Yu W, Qian Y (2004) Selected-control synthesis of $\mathrm{PbO}_{2}$ submicrometer-sized hollow spheres and $\mathrm{Pb}_{3} \mathrm{O}_{4}$ microtubes. Inorg Chem Commun 7:607-610

Xiao G, Wang Y, Ning J, Wei Y, Liu B, Yu WW, Zou G, Zou B (2013) Recent advances in IV-VI semiconductor nanocrystals: synthesis, mechanism, and applications. RSC Adv 3:8104-8130 